\title{
Towards A More Holistic Graduate Experience: Professional Service to the Discipline
}

\author{
Courtney N. Haun ${ }^{1}$ (chaun@samford.edu) and Ivy A.M. Cargile ${ }^{2}$ (icargile@ csub.edu)
}

\section{What You Need to Know}

Service during graduate school, can amplify student learning outcomes and bolster relationships within the academy (McFadden and Smeaton 2017; Sinha 2014). However, at the same time, too much time devoted to service may lead an undue level of stress (Valovick and Swegle 2020). The type and amount of service one provides to the discipline can look different across graduate students and across the time in the academic program. With that said, weighing the pros and cons of service is important while completing graduate program work.

In political science, service may consist of volunteering at one's political science department as well as assisting with the various sub-groups, caucuses, and affiliated groups that are a part of the larger national organization, the American Political Science Association (APSA), and the smaller regional organizations. Some of these groups have specific positions for graduate students, while others do not but are open to having graduate students fill them. Some organizations, such as the Midwest Political Science Association, hire graduate students in order to help with membership and the planning of the annual meeting. While this latter opportunity is a paid one, as opposed to most which are volunteer based, it is still an effective way to get involved with the discipline outside of one's own institution. Similarly, at the APSA there is also

\footnotetext{
${ }^{1}$ Assistant Professor, Dept of Healthcare Admin and Informatics, Samford University

${ }^{2}$ Associate Professor, Dept of Political Science, California State University, Bakersfield
} 
the opportunity to be involved with a recently created group: the Graduate Student Status Committee. Its focus is to give graduate students a voice on important decisions made by the larger organization, as well as to provide professionalization opportunities. Then for some graduate students, there are other helpful pathways to partake in service that are paved by their faculty advisors. For instance, some graduate students have the opportunity to work with various journal editors (who are faculty) in managing the submissions of manuscripts for possible publications.

As a graduate student it is easy to fall into the trap of thinking that service to the discipline is not something to do, either because one has not yet finished the graduate program and thus has not yet secured full-time employment, or that it is simply not important. The latter is primarily driven by all of the different responsibilities that graduate students juggle - primarily those of course work, comprehensive examination preparation, dissertation creation, etc. all while trying to publish manuscripts as an early scholar. However, providing service to the discipline of political science can yield important benefits that are worth considering.

By volunteering to conduct service, one of the immediate benefits is the opportunity to expand one's professional network, which can prove helpful not just in the immediate short term but in the long run throughout one's career. As a graduate student, it is valuable to know both faculty and graduate students who are not a part of one's own program. Not only does it lend itself to co-authorship opportunities, but also to hearing the perspectives and the experiences of professionals outside of one's institution. Another possible benefit is learning how things get accomplished within the discipline broadly, as well as the professional organizations that are vital to the academy. Lastly, it can also help with the development of leadership traits that can be useful as one journeys from graduate student to career professional. Overall, there are a variety 
of benefits from taking part in service, including but not limited to enriching a students' future career prospects, building professional networks, and providing a favorable impression among colleagues in the field.

\section{Why Service Matters}

Service to the discipline of political science is often on a volunteer basis. As such, what opportunities a student decides to get involved with needs to be carefully evaluated, especially when juggling course work, comprehensive exams, and teacher and research assistant duties. As a result, it is important that while giving their time, graduate students also be selective in what they choose to do. In a sense, graduate students want to be strategic and volunteer to do service work that will either enhance a skillset or that will help to take a "mental break" from school/academic work. Regardless of the reasons for deciding to complete service work, another reality to consider is that despite drawbacks such as losing time allocated for reading and writing, there also exist several benefits (Brock 2012).

By expanding one's professional network, it is possible to increase and vary the number of graduate students and faculty one is familiar with across various universities and departments. As previously mentioned, a wider network can not only result in opportunities to co-author with other graduate students or faculty who have shared research interests, but it can also result in the opportunity to learn about the numerous ways that other political science departments function, based on the experiences of those ones is meeting while serving. This can be beneficial when getting ready to go on the job market and figuring out what skills, approaches, and overall content should be highlighted in job packets. In addition, it is also possible to increase the level of knowledge one has about scholarships, fellowships, grants, and other assorted opportunities that assist, enhance, and help fund the graduate school experience. 
The opportunity to serve as a graduate student can also enrich leadership skills (Brock, 2012). For instance, if the choice is to serve as a graduate student representative of a sub-group or affiliated group within the national or regional organizations, it is possible to get a behind the scenes look at how business meetings are run, and how award committees function. This kind of experience provides good insight into how to lead business meetings, how to feel confident in being in front of colleagues from different universities, and how to present important organizational information. While doing presentations is part of the training graduate students receive, leading professional meetings can be different. Especially when doing so in front of senior professionals who are not quite colleagues yet. By choosing to provide service in this way, graduate students have the chance to see how things are run and how others handle leadership in order to decipher for themselves how they want to develop as leaders. Additionally, there is also the possibility that some service roles may provide for the opportunity to advocate for better support and resources for students broadly and/or for underrepresented and underserved student populations.

Unfortunately, there are still many processes that are a mystery and are left untold, both when in graduate school and after graduation as one transitions from student to professional. However, this is why deciding to volunteer and engage in service to the broader discipline can be helpful. It provides insight and knowledge that one might not otherwise receive while in graduate school yet will be helpful in navigating one's career.

\section{Interested in Service: Insight for Getting Involved}

There are many different types of service opportunities that are available to you. However, not all of these activities and opportunities will be of interest to you, nor will they fit your future career outlook. In addition, there are unique professional service opportunities in the 
field of political science. As a graduate student in this field, it is important to spend some time figuring out the service opportunities that are available and would be of interest to you to get involved in. This requires "getting a lay of the land" in terms of the differing levels of service (i.e., at the department, college, and university levels as well as external organizational levels).

First, figure out what is going on within the department. This may or may not be covered during initial orientation before starting one's program. Take it a step further by meeting with the Department Chair to unveil professional service opportunities. Some examples include political science specific student organizations and societies (e.g., Pi Sigma Alpha), serving as a student representative on a hiring committee, or hosting an election conference. There also could be some service opportunities at the college/university one attends that would be of interest. During the meeting with the Department Chair, it is possible to ask about this as well as searching online.

Another action item is exploring service in external organizations related to political science. Discussion with other students, faculty, and research you conduct online will be beneficial. Although it is difficult to speak to the service available at the department and college/university level because of the uniqueness that comes along with each setting, political science organizations will be expanded upon. The following will highlight some of these by looking at some of the various associations, research outlets, and industry in general.

Political science associations, such as the American Political Science Association, are places where students can get involved at multiple levels. The following table provides a list of organizations at the international, national, and regional level. To note, there very likely other affiliated organizations at the state, local, and chapter level. 
Table 1: Organizations Graduate Students Can Pick From

\begin{tabular}{|c|c|c|}
\hline International & National & Regional \\
\hline $\begin{array}{l}\text { International Studies Associ } \\
\text { ation }(\underline{\mathrm{ISA}})\end{array}$ & $\begin{array}{l}\text { The } \\
\text { American Political Science } \\
\text { Association (APSA) }\end{array}$ & $\begin{array}{l}\text { New England Political Scien } \\
\text { ce Association }\end{array}$ \\
\hline $\begin{array}{l}\text { International Political Scienc } \\
\text { e Association (IPSA) }\end{array}$ & $\begin{array}{l}\text { Academy of Political Science } \\
(\underline{\text { APS }})\end{array}$ & $\begin{array}{l}\text { Midwest Political Science } \\
\underline{\text { Association }}\end{array}$ \\
\hline \multirow[t]{4}{*}{$\begin{array}{l}\text { Association for } \\
\text { the Study of Nationalities ( } \underline{A} \\
\underline{\text { SN) }}\end{array}$} & $\begin{array}{l}\text { National Academy of Public } \\
\text { Administration (NAPA) }\end{array}$ & $\begin{array}{l}\text { Western Political Science } \\
\text { Association (WPSA) }\end{array}$ \\
\hline & $\begin{array}{l}\text { International City/County } \\
\text { Management Association } \\
\text { (ICMA) }\end{array}$ & $\begin{array}{l}\text { Southwestern Political Scien } \\
\text { ce Association ( } \underline{\text { SSSA })}\end{array}$ \\
\hline & $\begin{array}{l}\text { National Association } \\
\text { of Schools of } \\
\text { Public Affairs and } \\
\text { Administration (NASPAA) }\end{array}$ & $\begin{array}{l}\text { Southern Political Science } \\
\text { Association (SPSA) }\end{array}$ \\
\hline & $\begin{array}{l}\text { National Conference of Black } \\
\text { Political Scientists } \\
(\text { NCOBPS })\end{array}$ & \\
\hline
\end{tabular}

For those with a career outlook in academia, they may also be interested in serving journal outlets (e.g., American Journal of Political Science, Politics Groups \& Identities) and conferences that are linked to the organizations mentioned above. There may be opportunities to 
review papers, help organize a conference or conference panels, lead in a local chapter, and more. Those who are interested in academia or going into industry may also see value in professional service through volunteer work or non-paid internships (see Chapter 10 on internships while in graduate school). These opportunities vary based on one's particular areas of focus in the field of political science.

The biggest action that can be taken is making a list of these opportunities. Then, spending time narrowing that list down to the opportunities that are of most interest while aligning future career goals and objectives. After that, a clearer idea of what service opportunities are available and of interest will surface. This does not mean one should be involved with every single item on the list or that one will have the resources to do so. More on that below.

\section{How to Plan for Service}

When it comes to resources, there is only so much time and available funding for students. Service inevitably takes time. Membership in professional organizations inevitably costs money, although typically at a discounted rate for students. In some cases, departments are willing to cover student membership costs for organizations in which they are participating or serving. However, that is not always the case, and the student may have to incur that cost. With that said, the list from above and the opportunities you are interested can be further narrowed down with time and funding in mind.

Questions to be asking oneself - "How much time do I have to give to service?" and "How much funding is available to me to partake in service (if that is a requirement)?" Of course, service can be beneficial for networking, preparing for the job market, and achieving a 
better understanding of how the academy and political sciences in general function. However, there must be balance in how much service a student takes on.

A smart step to take is to create a "time budget" for service activities. For example, if in the process of completing course work then it is likely that there is time to serve at least one conference each academic year. It is important to test the time budget and modify accordingly. Each semester may look a bit different, with the budget increasing during one term while decreasing in another. In general, service lengths and time commitments do vary from a one to four hour need to review manuscripts, or two to three months for conference event preparation, or even a yearlong (sometimes multiple yearlong) commitments on a standing committee. These time allocations should be weighed with due diligence in order to avoid over committing and not spending enough time focusing on making progress towards finishing one's program. Also, it is important to not forget to keep a record of service activities by adding them to the curriculum vitae/resume and LinkedIn profile. Through service, there is the building of the professional network of current and future colleagues, as well as helping the field of political science prosper.

\section{Personal Reflections}

The authors' personal reflections of service are provided to help bring to light some examples of these roles during graduate school. In the academic setting, research mentors made it apparent that reviewing papers for conferences would be a good way to gauge quality of writing, learn more about the acceptance process, and volunteer for differing organizations. Reviewing papers for conferences typically took place once a year with one to three papers to review. The overall time commitment was three to five hours. This was a learning experience 
that illuminated how the review process works and the importance of volunteers for the conference to operate with academic integrity and rigor.

Another example is a service appointment that occurred through a conversation at a conference. Leadership was planning for the next year and made an announcement that they needed help with their website. This turned into a formal appointment with the statewide organization as Director of Communications, and it developed into various other leadership roles held within the organization during graduate school. Although two very different time commitments and roles, both service opportunities turned into strong relationships with colleagues, while cultivating experiences that paid dividends through aiding preparation for academic work, such as writing and publishing.

Other experiences the authors have had as graduate students include serving as the graduate representative for a standing committee organized by members of a regional conference. For this kind of service, the appointment was for an entire academic year. Yet in terms of actual time spent focusing on work for the committee, the expectation was a total of about 4-6 hours. The bulk of the work entailed working with the group's executive team to put forth ideas on recruiting more graduate students to join the standing committee. Additionally, attending the annual regional meeting, while not required, was definitely helpful for purposes of connecting with and reporting updates to the rest of the membership. Engaging in this kind of service yielded benefits that outweighed the costs, due to the ability to network with academics in various stages of their careers and receive valuable insight into life after graduate school.

It is important to also highlight that as a graduate student it is also possible to provide service to one's own department. One way to do this is through volunteering to serve as the graduate student representative on hiring committees of possible new faculty. This commitment 
does take time away from one's schedule. But it is usually for a period of about 4-6 weeks, with the majority of the work happening towards the end when application packets are due to the department. Reviewing job packets will consume time and so will the campus visits - especially if there is scheduled time for a student Q\&A session. However, despite the cost in time that this opportunity demands, it is worth it given that it is possible to witness the hiring process and be privy to the conversations had by the committee about various issues such as fit.

\section{Conclusion}

Professional service is of extreme importance during the political science graduate school journey. Through service endeavors, students have the opportunity to build the foundation for their professional network, among other benefits. However, one should be weary of giving too much time to service commitments, as there are larger goals that should be the focus. There is a need for balance between program obligations (e.g., course work, assistantships, etc.) and service projects. In the world of political science, there are a vast amount of service engagement opportunities, including with the APSA as well as regional organizations, journals, and other various activities.

The "time budget" should be consulted while deciding if one should add and/or modify service commitments. In considering how much time there is to meet all the necessary deadlines it is also important to consider what benefits will be gained from deciding to volunteer time and energy towards a service project. Deciding to provide service to the broader discipline as a graduate student is a smart way to prepare and begin learning how to balance the different responsibilities that will demand time and energy once graduate school is over and the professional career, academic or not, begins. 


\section{References}

Brock, Terry. "Professional Service: Getting Involved in Your Discipline." Gradhacker (blog), The Chronicle of Higher Education, April 08, 2012. https://www.insidehighered.com/blogs/gradhacker/professional-service-getting-involvedyour-discipline.

McFadden, Amanda, and Kathleen Smeaton. "Amplifying student learning through volunteering." Journal of University Teaching \& Learning Practice 14, no. 3 (2017): 6.

Sinha, Sharad. "The benefits of volunteering." IEEE Potentials 33, no. 3 (2014): 30-31.

Valovick, Kyra, and Kelsey Swegle. "The Effect of Volunteering on Stress Hormone Levels of Graduate Student Volunteers." (2020).

\section{Links in Table}

https://www.isanet.org/

https://www.ipsa.org/

https://nationalities.org/

https://www.apsanet.org/ABOUT/About-APSA

https://www.psqonline.org/AboutAPS.cfm

https://napawash.org/

https://icma.org/

https://www.naspaa.org/ 
https://www.ncobps.org/

https://www.nepsanet.org/

https://www.mpsanet.org/

http://www.wpsanet.org/

https://sssaonline.org/affiliates/southwestern-political-science-association/

https://spsa.net/ 